\title{
Private Security and Municipal Policing in Academic Education - An International Overview ${ }^{1}$
}

\section{KOVÁCS Éva - CHRISTIÁN László ${ }^{2}$}

\begin{abstract}
The objective of the research group entitled The role of private security and local governmental law enforcement in 21 st century law enforcement is to comprehensively examine the field of private and municipal policing regarding its domestic situation with an international outlook. Analysing this issue, the question of how, in what detail and at which training levels the education of these two fields are conducted bears utmost importance in countries under our scrutiny, along with regulatory, organisational and operational issues. The selection of the countries was done subjectively, in line with the work of our research group.
\end{abstract}

Keywords: municipal policing, local governmental law enforcement, private security, university, academic education

\section{Definition of Private Security and Local Governmental Law Enforcement}

Public safety is the collective product of society, which consists of the activities of the individuals and communities, the official measures of the state organisations, the capability of the citizens to protect themselves and the services of the entrepreneurial market. ${ }^{3}$ We can realise that nowadays security is also a collective and cooperative product of the society, due to the participation of state and local level organisations, volunteers and the private security sector. The Hungarian law enforcement system is based on public order organisations (Police, Disaster Management, Civil National Security Service, Prison Service), however, there are some other "complementary law enforcement" institutions, which play a role. ${ }^{4}$

\footnotetext{
The work was created in commission of the National University of Public Service under the priority project PACSDOP2.1.2-CCHOP-15-2016-00001 entitled "Public Service Development Establishing Good Governance" in the Ludovika Workshop.

2 Éva KOVÁCS, language teacher, National University of Public Service, Foreign and Technical Languages Centre orcid.org/0000-0003-3295-9243, kovacse@uni-nke.hu

László CHRISTIÁN, PhD, Police Colonel, Associate Professor, National University of Public Service, Faculty of Law Enforcement, Department of Private Security and Local Governmental Law Enforcement orcid.org/0000-0001-9809-4890, christian.laszlo@uni-nke.hu

3 Finszter (2001) 53-66.

4 Christián (2017) 132-139.
} 
Private security is a service provided by an authorized market participant (either an enterprise or a natural person) in return for a service charge, which protects the personal safety and property of the client, facilitating the exercise of rights on a broader scale. In our view, private security can be perceived as a mathematical set, creating larger and larger common subsets with public order and safety, while having its considerable own subgroup, as well. It has become a global tendency in the recent years that the role of private security actors is increasing within the system of law enforcement. The main reason for this we regard to be the fact that they offer both specialised and comprehensive services equally at a professional level. Before defining the term "local governmental law enforcement", it is important to explain a detail: this is the officially used term. In general, the international usage applies the term "municipal policing", yet, in countries with more centralized police such as Hungary, we may only describe the existing structure as "local governmental law enforcement" since the Hungarian police force is centralised and single, therefore there is no possible way to establish police forces controlled by local governments. ${ }^{5}$

The so-called "municipal police model" around Europe means that decentralised police units co-exist under municipality control parallel with the state police with similar empowerment. The municipal bodies respond to local needs in close cooperation with other law enforcement organisations.

The Hungarian local governmental law enforcement bodies are founded and financed by the municipalities with more limited empowerment to enforce the law than that of the police. Their main role is to contribute to public security, crime prevention with respect to residential needs and requests, protection of local assets and to improve the subjective sense of security of the population. According to another expert from this field, we can define local governmental law enforcement as all the activities and direct actions taken in response to the demand of local security issues. The competence and powers of local governmental law enforcement bodies are more limited than those of the police. The most important type of local governmental law enforcement unit is the Public Area Surveillance Unit; almost all major cities and towns established this kind of unit. ${ }^{6}$

Regarding the fact that private security and local governmental law enforcement comprise a peripheral field of law enforcement, it is crucial to examine how individual countries replenish the new supplies of professionals and what sort of training options are available for them in tertiary education. The present study introduces the Hungarian trainings in higher education, coupled with a brief international outlook on relevant international academic tuition.

Bacsárdi-Christián (2016) 84-98.

Christián (2016) 695-698. 


\section{Domestic Situation}

Private security is dealt with at two academic institutions in Hungary, whereas local governmentallaw enforcement studies are available at only one university (NUPS). Security managerialtrainingisavailableattheNationalUniversityofPublicService, whiletwofaculties of Óbuda University are concerned with security technology engineering education. The National University of Public Service ${ }^{7}$ started its operation on 1 January 2012 with the integration of three predecessors in title faculties (military and police officer training, public administration), now comprising five faculties altogether. The mission of the university is the creation of new supply of professionals in public administration with regard to interoperability between careers.

The monopoly of policing training among Hungarian academic institutions is held by the Faculty of Law Enforcement at the National University of Public Service, whose predecessor in title was the Police College. This institution carries out the teaching of private security and local governmental law enforcement professionals and experts. Students receive a comprehensive knowledge in fundamental legal fields (constitutional, administrative, criminal and civil law, etc.) and various special managerial and vocational law enforcement courses. The vocational core material includes up to 40 subjects with a wide knowledge from basic courses such as the theoretical fundaments of private security, personal protection and safety, property protection, event protection policy and security technology. Special subjects include the security of commercial units, cooperation in law enforcement, operational conditions in property protection businesses, data security and protection.

The major offers two specializations for private detection and information security specialization, and local governmental law enforcement. The subjects belonging to both specializations are taught in an increased number of hours.

A closely connected antecedent of the present tuition was the fact that the Police College, the preceding institution in title opened its doors to the civilian public in the year 2000, startingapost-secondaryvocationaltrainingentitled "crimepreventionorganizer". The extraordinary popularity of the course prompted the leaders of the institution to offer courses for businesses in the line of private security and municipal law enforcement. Eventually, 2006-2007 marked the kick-off year in academic-level academic education in the form of specialization for security. Since the foundation of the courses for security and due to its higher educational level tuition, the actors in the area are increasingly supportive of the notion that the creation of complex security may not exclusively be expected from the police, but alternative participants must also be involved in it. The security specialization has drawn significant interest from the world of private security, municipal policing and even traditional law enforcement with numerous private security business leaders and local governmental law enforcement experts having completed their education here.

7 https://en.uni-nke.hu/ 
In the fall of 2013, in order to cater for the security specialization, a new department was established under the name: Department of Private Security and Local Governmental Law Enforcement. The responsibility of the state lies behind this decision, realizing that the key factor of professional development and lawful operation in the area depends on improving quality multi-level academic education. The six-semester security regular bachelor tuition is available for 20 students annually; in parallel, the correspondence bachelor training is accessible for 750 EUR per semester. The regular bachelor training is available for anyone, where the ranking of applicants is based on the points scored in secondary schools. In addition to this, there is a psychological entry test and a career guidance conversation as part of the admission. Students of regular bachelor tuition must complete a four-week professional practice in their first and second year, with an added two weeks in their third year, at the partner enterprises presented by the Department. In the current academic year of 2017-2018, a total of 45 regular and 60 correspondence undergraduates are studying. The number of applicants has risen considerably in the past few years, raising pass scores for admission, together with the prestige and acceptance of the trade itself. Admission scores for the security specialization have increased by 73 points from 258 to 331, and in the last academic year the training has reached its maximum headcount of 20 with the 1 st year students. Not surprisingly, the renewed training has drawn the attention and support of 20 influential representative enterprises of the profession, in a form of a contract of cooperation with the university. In accordance with the general official law enforcement nature of education at the faculty, since the autumn of 2017, undergraduates have been wearing a quality uniform and are preparing for their future security managerial profession in their own well-equipped private security and local governmental law enforcement specialized classrooms. Graduate students may now enjoy a wide selection of job offers.

The university regards the field a priority by allowing the establishment of an own research group within the department, and also by facilitating the introduction of master education.

\section{Óbuda University ${ }^{8}$}

Based in Budapest, the Technical University of Óbuda has two faculties with relevant training to private security. In 1993, security technology engineering training started in Budapest Polytechnic. The two members of this educational association were Bánki Donát College of Mechanical Engineering and Bolyai János College of Military Technology, where the regular training of security technology engineering began. The former institution introduced a correspondence academic training in 1999. From 1996 until 2000, an intensive cooperation between the two institutions ensured for professors the possibility of cross-teaching relevant to the profile of the gi-

$8 \quad$ www.uni-obuda.hu/en 
ven education and their own expertise. In 1999, the accreditation process of security technology engineering education was successfully completed in both institutions. The cooperation was transformed when the independence of these colleges was discontinued. The former institution has become the member of Budapest Technical College as Bánki Donát Faculty of Mechanical Engineering, while the latter integrated into the Zrínyi Miklós National Defense University, also as a college faculty. Following the joining to the Bologna Process, these new institutions commonly started the bachelor education of security technology engineering as one specialization of military and security technology engineering in September 2005. In both institutions, the educational experience, infrastructure and the sufficient tutorial staff contributed to the start of the master studies in September 2006, completing the old official name with a new phrase to become Bánki Donát Faculty of Mechanical Engineering and Security Technology. On the 1st of January 2010, Óbuda University was established, whose predecessor in title was the Budapest Technical College. The Doctoral School on Safety and Security Sciences at Óbuda University was accredited in 2012, making it possible to continue the studies after the master's degree at an academic level. By 2015, the successor of the former Zrínyi Miklós National Defense University, the National University of Public Service discontinued all trainings regarding security technology engineering. This means that now, the full scope of this training is available exclusively at the Bánki Donát Faculty of Mechanical and Safety Engineering at Óbuda University. Currently, the security technology engineering tuition boasts a total of 630 undergraduates at its BSc, and MSc, regular and correspondence studies, and 130 postgraduates in its Doctoral School. Kandó Kálmán Faculty of Electric Engineering at Óbuda University has an institute dealing with automation and instrument technology where students can design and develop remote monitoring and electronic property protection systems.

\section{International Overview}

\section{Berlin $^{9}$}

The Berlin School of Economics and Law currently operates five departments and three institutions. The Department of Police and Security Management has maintained education since 2011. The department offers two majors, one for police studies, the other in security management, having both bachelor and master courses. The seven-semester bachelor security management (Sicherheitsmanagement) tuition is available solely for 40-50 regular students annually. The training is free of charge and state-financed. Compared to Hungarian circumstances, the workload on students is more favourable with an average of 20 lessons per week and a practise-driven training.

www.hwr-berlin.de/en/department-of-police-and-security-management/study-programmes/international-securitymanagement/ 
Semester 5 is fully dedicated to practice, additionally, students are to complete a fourweek practice per each semester (with the exception being semester 5 and 7 ), having completed 38 weeks of practice by the end of their bachelor studies.

They include 21 compulsory and 6 optional modules, with numerous fundamental and professional subjects, plus they also emphasize other significant areas such as handling security risks and crisis, self and conflict management.

In case of security management, the master training requires BA qualification and a minimum yearlong work experience. It is conducted under the name of MA in International Security Management, suggesting the opportunity to gain a transferable qualification across borders for future security managers. The MA course including subjects on risk, crisis and catastrophe management, protection of critical infrastructures and quality assurance issues typically relevant for middle or top management of private enterprises with various lines of businesses. Most students arrive from private security companies, authorities as well as the law enforcement and military sector with the prospective of a possible alternative career path. Students complete a certain part of the modules using distance learning and active online consultation which leaves them with 4 to 5 contact occasions requiring their personal attendance per semester. As a characteristic feature of the training, a seven-member consultant board provide aid in order to maintain an updated course material, develop education as well as to enhance the work of professors. It is interesting to note that the Berlin School of Economics and Law is in close co-operation with many other universities. ${ }^{10}$

\section{University of Maribor, Faculty of Criminal Justice and Security (Ljubljana, Slovenia) ${ }^{11}$}

At the University of Maribor, the Faculty of Criminal Justice and Security deals with the education of students involved in security science. At all three levels of the tuition (BA, MA, Doctoral level), the institution shows links to community and private policing, with an in-depth insight into self-organised individual and group security, business security in economic enterprises, private investigation and counselling and local community security issues. The dean of the aforementioned department, Dr. Andrej Sotlar takes part in the work of our research group which began its operation in September 2017. In 2008-2009, the Faculty of Criminal Justice and Security fully implemented three new first-cycle undergraduate study programmes designed according to the Bologna Declaration guidelines. Two of them are professional study programmes, "security and policing" and "information security", while criminal justice and security is an academic study programme.

The criminal justice and security study programme is a postgraduate two-year and second-cycle or master's study programme. The programme is, first of all, a continua-

\footnotetext{
Fórizs (2015) 57-66.

www.fvv.um.si/en/
} 
tion of the faculty's first-cycle academic study programme and is comparable to study programmes such as the first-cycle study of "security and police work" and the study of "information security".

Under the title Criminal Justice and Security Studies, the University of Maribor also offers a three-year 3rd cycle Bologna doctoral study programme in the field of criminal justice and security. The goal of the doctoral study programme is to provide experts in the field of criminal justice and security with extensive knowledge and a broad perspective of social sciences.

\section{Danube University (Krems, Austria)}

Although the central focus of the studies at Danube University Krems (Donau-Universität) is on economics and business management studies at the faculty of our line of interest (Economics and Business Management), it also operates a separate major entitled Security Management. The university courses teach modern methods for preventive assurance of safety and aversion of danger. The target groups include security officials in companies and organizations, risk managers, safety planners (architects, civil engineers) and experts in the security industry. ${ }^{12}$ The target audience of the trainings detailed below arrives from the security field working both in the state sector and the private industry. The executional form of the education is the so-called "blended learning", supported by participants of the profession. The following courses are available within the specialisation:

- "fire safety expert", 3 semester-long training for a fee of 9,400 EUR in the form of blended learning

- "fire safety expert", a high-level training ending with a Master of Science qualification. The full training lasts for four semesters and costs 14,700 EUR, and is executed in the form of blended learning

- "information security management" qualification is available in two forms, one, in the form of two-semester long professional, and the other in a four-semester MSc education, with a fee of 6,900 and 15,900 EUR for the full length, respectively

- "security and safety management", the four-semester long training is available at master level for 15,900 EUR for the full length, in a form of blended learning

- "event security and crowd protection" is a two-semester long professional training for 5,900 EUR

12 www.donauuni.ac.at/en/studium/wirtschaft_unternehmensfuehrung/sicherheitsmanagement/index.php 


\section{University of Security Management (Kosice, Slovakia) ${ }^{13}$}

Established in 2006, this private university (USM) runs a number of projects of domestic and European Union interests, making this practise-oriented research the major profile of this state and EU-financed institution. ${ }^{14}$ There has been a scientific and technical cooperation with the Faculty of Special Engineering, University of Zilina, the university which USM laid its foundation five years ago as a detached office. USM claims its objective to be the provision of theoretical and practical knowledge in the field of crime, adjusting its bachelor study programmes accordingly, under the names Management of Security Systems and Protection of Persons and Property. The university falls under the category of "non-faculty", with organisational units being named as institutions.

\section{The United States of America}

"Although private security, as an essential element of society has been present since the beginning of civilization"15 we can state that the cradle of modern private security was the United States of America. As it happens with many other major areas of life, the regulation of education regarding our field of interest varies state by state. ${ }^{16}$ In higher education institutions where security studies are included in the curriculum, as a rule, a major objective is to teach security sciences comprehensively, not compelling students to make "either-or" choices. The subjects overlap in their material, creating a complex, intertwining system where critical thinking, creativity, responsible behaviour and problem solving are in the focal point among the acquired skills. Security sciences fall into three major categories, such as information security, risk management and physical security, with the latter having the highest, but not the exclusive relevance to local governmental and private policing. Professor Mahesh Nalla of Michigan State University participates as a foreign participant in the operation of our present research group.

\section{Local (Municipal) Policing Education Overview}

\section{Spain (Catalonia Autonomous Community)}

In 2007 a new law unified the former Police School and the School of Firefighters and Civil Protection, forming the Institute of Public Safety of Catalonia (ISPC), which depends directly on the Ministry of the Interior, Institutional Relations and Participa-

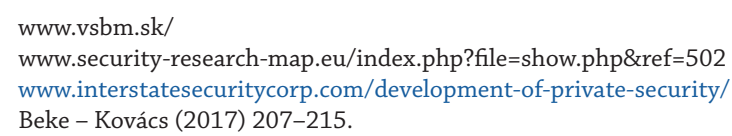


tion, and on Catalonia's regional government, Generalitat de Catalunya. Maintained by the Catalonian province, ISPC, as part of the University of Barcelona (Universitat de Barcelona), it is the key participant in law enforcement education, providing equal tuition for both provincial and local level polices and police officers. Furthermore, ISPC trains future firefighters and civilian skilled security professionals. The institute is entitled to conduct bachelor and master level education, with the former teaching the fundamentals of security, and the latter performing security strategy, civil protection, prevention, rescue and environmental protection service, as well as cyber security education.

\section{France}

Unlike the Spanish example, police and municipal police training is separated in France. France's National Police College (École Nationale Supérieure de la Police, ENSP) is responsible for the training of future police officers, while law governmental law enforcers are educated at the Centre National de la Fonction Publique Territoriale (CNFPT). Under the supervision of the Ministry of the Interior, the institute in tertiary education ENSP, in addition to conducting police officer training, is involved in various research programmes. At CNFPT, a compulsory entry training must be completed by municipal police officers (category $C$ ), rangers (category $C$ ), commanders of law enforcement services (category B) and director of law enforcement services (category A).

\section{Slovakia}

In Slovakia the Police Academy in Bratislava (Akadémia Policajného zboru v Bratislave, APZ) carries out the training of police officers. In addition to this, the academy caters for the needs of public administration, as well as non-state security services by offering tuition at three levels. At bachelor level, specialisations include: protection of property and persons, law enforcement and public administration. At master level, students can opt for specialisations at protection of property and persons and public administration security services. The doctoral school offers a maximal length of 3 years of training at regular, and 5 years at correspondence education. The University of Security Management in Kosice (USM) puts the operation of security systems, cyber security, financial operations security and traffic safety into its main focus. Although it does not carry out state police officer education, the institution conducts a number of vocational trainings and it also offers doctoral studies in business management. Municipal police officers in Slovakia are not required to obtain a degree in higher education, their vocational training is provided in the form of a course by the National Police Headquarters. The Ministry of the Interior is liable for their examination and the issuing of certificates. 


\section{The Czech Republic}

The state's law enforcement tertiary educational institution, the Police Academy of the Czech Republic (Policejní akademie České republiky v Praze, PA ČR) by law, operates under the responsibility of the Ministry of the Interior with two faculties: Faculty of Security and Law, and Faculty of Security Management. Both faculties offer courses at bachelor, master and doctoral level, covering the full spectrum of training. PA ČR trains not only state and municipal police officers, but colleagues for the Ministry of the Interior and other organisations of the state security system, as well as basic, middle and senior management roles in private security services.

\section{Conclusion}

With regard to the education of private security, we can observe two major tendencies. One is that the area shows a close connection with economic sciences and business studies, thus allowing a business-driven approach to its training, while the other considers the field of a constituent in the curriculum of law enforcement and legal studies. Yet, it is apparent from the educational programs examined that students with a wide scope of knowledge become qualified to fulfil positions in the private security industry where information and cyber security play an increasingly significant role. The field of local governmental law enforcement in academic tuition is scattered and infrequent.

\section{BIBLIOGRAPHY}

Bacsárdi, József - Christián, László (2016): Local governmental law enforcement in Hungary. In Meško, Gorazd - Lobnikar, Branko eds.: Criminal Justice and Security in Central and Eastern Europe: Safety, Security, and Social Control in Local Communities. Conference proceedings. Ljubljana, University of Maribor. 84-98.

Beke Éva - Kovács Tibor (2017): A biztonságtudománnyal kapcsolatos elvek és célkitűzések az Amerikai Egyesült Államok oktatási rendszerében. [Principles and Objectives of the Safety and Security Science in the Educational System of the United States.] Hadmérnök, Vol. 12, No. 4. 207-215.

Christián László ed. (2014): A magánbiztonság elméleti alapjai. Lecture notes. Budapest, NKE, RTK, MÖRT.

Christián László (2015a): Magánbiztonsági képzés - nem középiskolás fokon. In Biztonságpiac évkönyv 2015. 119-120.

Christián László (2015b): A magánbiztonság jövőjének kulcsai: minőségi képzés és kutatás. Detektor Plusz, Vol. 22, No. 2. 32-33.

Christián László (2015c): A magánbiztonság aktuális nemzetközi trendjei, rövid hazai helyzetértékeléssel. In Gaál Gyula - Hautzinger Zoltán eds.: Modernkori veszélyek rendészeti aspektusai. Pécsi Határör Tudományos Közlemények, XV. Pécs, 57-64. Source: www.pecshor.hu/periodika/XVI/christian.pdf (Downloaded: 08.01.2019.)

Christián László (2016): A rendőrség és rendészet. In Jakab András - Gajduschek György eds.: A magyar jogrendszer állapota. Budapest, MTA Társadalomtudományi Kutatóközpont. 695-698. Source: http://jog.tk.mta.hu/a-magyar-jogrendszer-allapota-kotet (Downloaded: 08.01.2019.) 
Christián, László (2017): The role of complementary law enforcement institutions in Hungary. Efficient synergy in the field of complementary law enforcement - a new approach. Public Security and Public Order, Vol. 18, 132-139.

Finszter, Géza (2001): The Share of Competence of State Authorities within the Sphere of Public Order and Safety protection in Hungary. In Widaczki, Jan - Maczynski, Marek - Czapska, Janina eds.: Local Community, Public Security. Central and Eastern European Countries under Transformation. Warszawa. 53-66.

Fórizs Sándor (2015): Magánbiztonsági képzés Berlinben. Magyar Rendészet, Vol. 15, No. 4. 57-66.

\section{Internet sources}

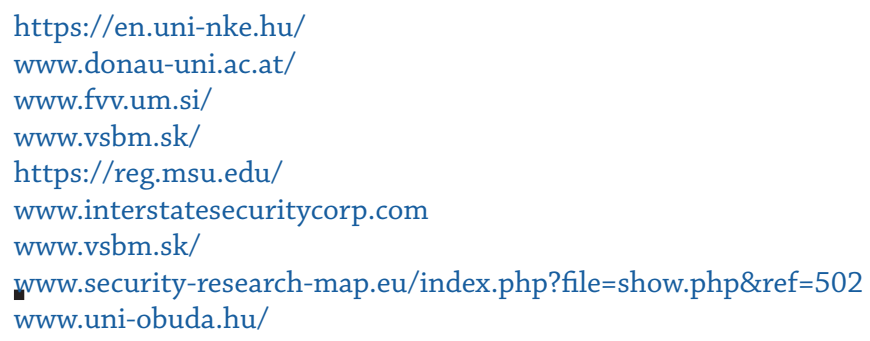

